\title{
Silicification in Grasses: Variation between Different Cell Types
}

\author{
Santosh Kumar, Milan Soukup and Rivka Elbaum* \\ Robert H. Smith Institute of Plant Sciences and Genetics in Agriculture, The Hebrew University of Jerusalem, Rehovot, Israel
}

Plants take up silicon as mono-silicic acid, which is released to soil by the weathering of silicate minerals. Silicic acid can be taken up by plant roots passively or actively, and later it is deposited in its polymerized form as amorphous hydrated silica. Major silica depositions in grasses occur in root endodermis, leaf epidermal cells, and outer epidermal cells of inflorescence bracts. Debates are rife about the mechanism of silica deposition, and two contrasting scenarios are often proposed to explain it. According to the passive mode of silicification, silica deposition is a result of silicic acid condensation due to dehydration, such as during transpirational loss of water from the aboveground organs. In general, silicification and transpiration are positively correlated, and continued silicification is sometimes observed after cell and tissue maturity. The other mode of silicification proposes the involvement of some biological factors, and is based on observations that silicification is not necessarily coupled with transpiration. Here, we

OPEN ACCESS

Edited by:

Rupesh Kailasrao Deshmukh, Laval University, Canada

Reviewed by: Gea Guerriero,

Luxembourg Institute of Science and Technology, Luxembourg

Martin John Hodson,

Oxford Brookes University, UK

*Correspondence: Rivka Elbaum rivka.elbaum@mail.huji.ac.il

Specialty section: This article was submitted to Plant Nutrition, a section of the journal Frontiers in Plant Science

Received: 06 February 2017 Accepted: 14 March 2017 Published: 28 March 2017

Citation:

Kumar S, Soukup M and Elbaum $R$ (2017) Silicification in Grasses: Variation between Different Cell Types. Front. Plant Sci. 8:438. doi: 10.3389/fpls.2017.00438 review evidence for both mechanisms of silicification, and propose that the deposition mechanism is specific to the cell type. Considering all the cell types together, our conclusion is that grass silica deposition can be divided into three modes: spontaneous cell wall silicification, directed cell wall silicification, and directed paramural silicification in silica cells.

Keywords: cell wall, grasses, inflorescence bracts, root endodermis, silica cells, silicification mechanism, transpiration, trichomes

\section{INTRODUCTION}

Silicon is a ubiquitous soil element that along with oxygen forms $50-70 \%$ of soil mass (Ma and Yamaji, 2006). Plant roots absorb silicon as mono-silicic acid $\left[\mathrm{Si}(\mathrm{OH})_{4}\right]$, a solute that is released to soil by the weathering of siliceous minerals. Near most soil $\mathrm{pH}$, silicic acid is an uncharged molecule with pKa 9.8. Its concentration in soil solutions usually varies between 0.1 to $0.6 \mathrm{mM}$, but may range anywhere between 0.01 to $2.0 \mathrm{mM}$ (Haynes, 2014). Silicon affects plants' physiology in many beneficial ways, imparting tolerance against biotic stresses and alleviating adverse effects of abiotic stresses (Liang et al., 2015). Although the benefits of silicon in agriculture are known for a long time, no general mechanism of action was defined.

Silicon content across plants varies between about $0.1 \%$ to more than $10 \%$ on dry weight basis (Epstein, 1994). Plants belonging to fern family Equisetaceae, and monocots belonging to families Poaceae, Cyperaceae, and Commelinaceae have relatively large silicon content of about 4\% (Hodson et al., 2005; Currie and Perry, 2007). Among them, Poaceae (the grass family) is the agriculturally most important family, with rice, wheat, and barley constituting the basis for human nutrition worldwide. In grasses, the root uptake of silicic acid (herein referred to as $\mathrm{Si}$ ) is mediated by the cooperative action of an aquaporin-like channel Low silicon 1 (Lsil) and a proton 
antiporter, Lsi2. Afterwards, Si moves with the transpiration stream and is unloaded from the xylem in the leaves by another aquaporin-like channel, Lsi6 (reviewed by Ma et al., 2011; Ma and Yamaji, 2015). In addition, so far unknown Si transporters might be involved in directing further Si transfer within the leaf tissues and concentrating it in target locations. The solute terminally polymerizes with concomitant loss of water molecules, forming hydrated silica $\left(\mathrm{SiO}_{2} \cdot \mathrm{nH}_{2} \mathrm{O}\right)$. Plant silicification occurs in cell walls, cell lumens, and intercellular spaces. While most of the mineral is found in the shoot, some Si polymerizes in the roots (Sangster, 1978).

Two contrasting hypotheses are often proposed to explain silica deposition. The first is based on a passive mode of silicification, relying on the spatial correlation between silica deposition and organ transpiration (Yoshida et al., 1962; Sangster and Parry, 1971; Rosen and Weiner, 1994; Euliss et al., 2005). In this case, specific cell wall components and cuticular structures may additionally affect the location of bio-silicification (reviewed by Exley, 2015; Guerriero et al., 2016). This hypothesis infers that silica deposition in plants is a spontaneous process resulting from auto-condensation of Si molecules as the sap undergoes dehydration (Yoshida et al., 1962). The second hypothesis suggests that the formation of plant silica structures is catalyzed by biological entities (Kaufman et al., 1969; Hayward and Parry, 1973; Sangster et al., 1983; Parry et al., 1984; Kumar et al., 2017). Some authors suggest that silica deposition cannot be explained solely by any one of the two hypotheses, and both the mechanisms may be involved simultaneously (Hayward and Parry, 1975; Sangster et al., 2001; Motomura et al., 2004; Markovich et al., 2015). A review of literature is thus pertinent to better understand this biomineralization process.

\section{SITES OF SILICIFICATION IN GRASSES}

Silica is deposited in all the organs of grasses. The most intensely silicified tissues are usually root endodermis, leaf epidermis, and abaxial epidermis of inflorescence bracts (Figure 1). In most cases, silica impregnates the cell walls, directly laid down onto the cell wall matrix (Bauer et al., 2011; He et al., 2013; Hodson, 2016). The composition of the silicifying matrix may vary between species and cell types, thus influencing silicification pattern (reviewed by Guerriero et al., 2016; Hodson, 2016). In particular, grasses have a unique hemicellulose composition, containing glucuronoarabinoxylan and mixed-linkage glucans, instead of the xyloglucan in non-commelinid monocots and dicots. Furthermore, grass cell walls contain more phenylpropanoids and less pectin compared with dicots (Guerriero et al., 2016). Silica is often proposed to crosslink the cell wall polymers, adding to their compressive strength (Currie and Perry, 2009; He et al., 2013; Kido et al., 2015), similar to the role of lignin in lignified walls (Salmén, 2015). In addition, structural tradeoff between silica, lignin and cellulose was observed in rice (Suzuki et al., 2012; Yamamoto et al., 2012) and in a number of wetland species (Schoelynck et al., 2010). As the metabolic costs of silica deposition were estimated to be 20 -fold lesser than that of lignification (Raven, 1983), silicification can present preferable solution for improving mechanical properties of plant tissues. However, silica seems not to provide water repelling properties comparable to lignin and its utilization thus require some degree of regulation (Soukup et al., 2017).

\section{Silicification in Inflorescence Bracts}

Translocation of Si in plants is driven mostly by transpiration (Sangster and Parry, 1971), and coordinated by specific distribution of $\mathrm{Si}$ transporters. Silicic acid is selectively transported to the panicle of rice during its maturation (Yamaji et al., 2015), possibly due to its increasing sink strength (Detmann et al., 2013). In panicles, Si is concentrated and deposited in the inflorescence bracts (Hodson and Sangster, 1988), which serve as a tough protecting shield to the developing caryopses. Silica deposition is restricted to the epicarp hairs (Bennett and Parry, 1981; Parry et al., 1984) and the outer wall of aleurone layer (Hodson and Parry, 1982), whereas it does not accumulate in the caryopsis endosperm (Jones et al., 1963). Bract silicification also provides a safe disposing location for the mineral, which would polymerize anyway, as the transpired water evaporates.

\section{Silicification of the Glume Prickle Hairs, Papillae, and Long Cells}

The abaxial epidermis of the Phalaris canariensis glume consists of stomatal complexes, long cells, prickle hairs, papillae, marcohairs and silica-cork cell pairs (Hodson et al., 1985). Figure 1B shows a scanning electron micrograph of a Triticum aestivum (wheat) glume, exhibiting stomata, prickle hairs, papillae, and macro-hairs. In this section we will discuss silicification in glume prickle hairs, papillae and long cells, whereas the silicification of silica cell will be discussed in a separate section. Presence of stomatal complexes on the abaxial epidermis indicates substantial transpiration after their emergence. Nevertheless, the outer tangential cell wall of papillae and prickle hair tips are already silicified at emergence (Sangster et al., 1983; Hodson et al., 1985). The flag leaf sheath encloses the inflorescence before emergence and limits its transpiration, raising the possibility that the cell wall is conducive for spontaneous silica deposition (Nissan et al., 2015). Callose $[\beta-(1 \rightarrow 3)$-D-polyglucose $]$ induces silica deposition in undersaturated silicic acid solution (Law and Exley, 2011), and it is possible that similarly, other polysaccharides might play such role in cell wall silicification. Cross-sections of mature prickle hairs and papillae show that the lumen of these cells is also filled with silica, without the in-growth of cell wall into the cell lumen to template the silicification (Hodson et al., 1985; Hodson, 2016). Lumen silicification in dead cells suggests that it might be driven either by passive transpiration via silica granule formation (Bennett, 1982), or templated by organic matrix that is accessible to Si only after cell death (Sangster, 1970). However, the fact that lumen silicification continues long after cell death rather supports the transpiration driven passive mode of silicification. Thus, it might be possible that silica is deposited in two stages in these cells, starting at the tip and the outer wall induced by wall materials, followed by a spontaneous precipitation inside the lumen driven by the degradation of the protoplast and evapotranspiration (Motomura et al., 2006; Markovich et al., 2015). 

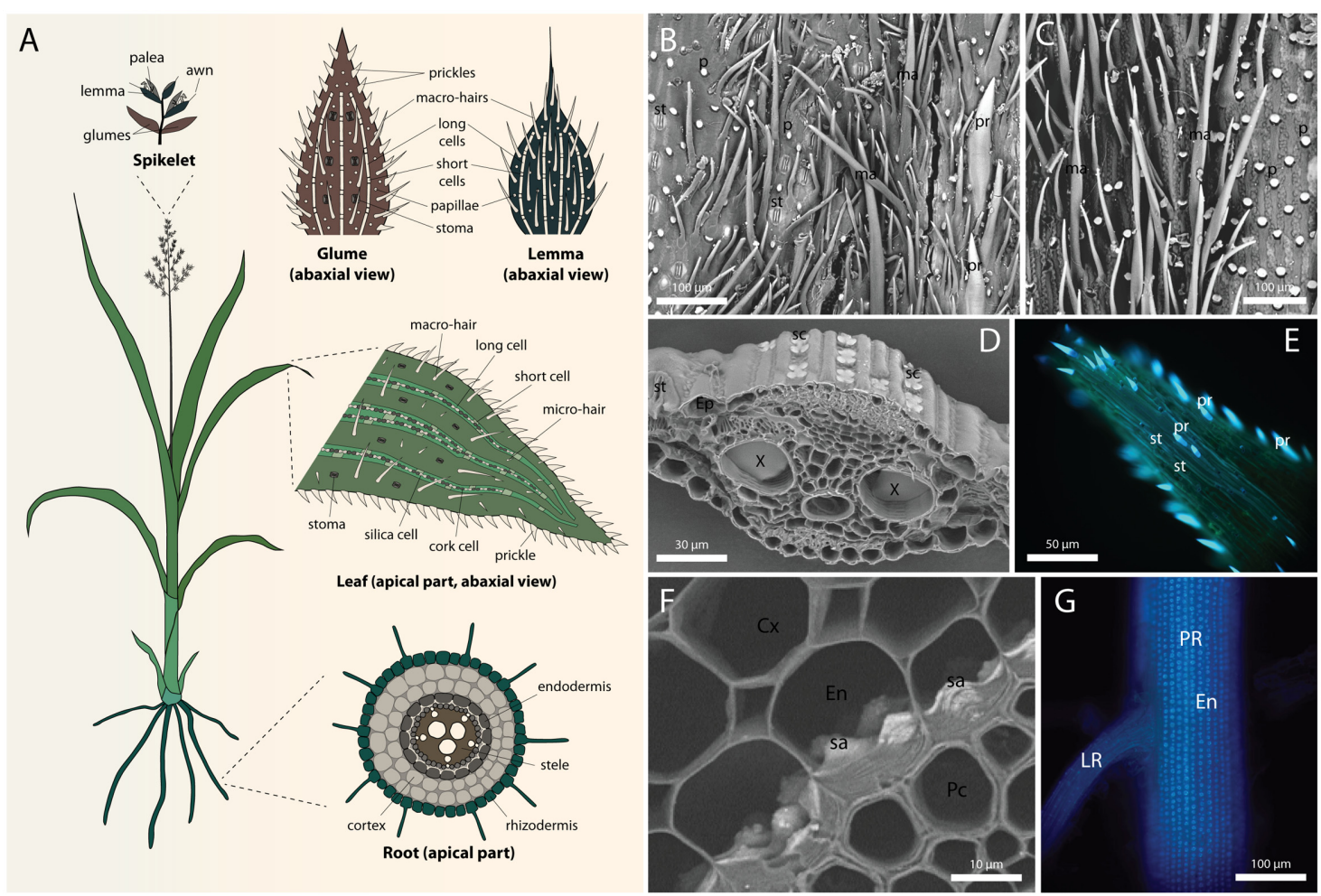

FIGURE 1 | Silica deposition in grasses. (A) Diagram showing a full view of a generalized grass, and typical silicification patterns in the inflorescence (top), leaf epidermis (middle), and root cross-section (bottom). White represent silicified cells. (B) Scanning electron micrograph (SEM) of the abaxial epidermis of glume in Triticum aestivum L. (C) SEM of the abaxial epidermis of lemma in T. aestivum. (D) SEM of Sorghum bicolor (L.) Moench leaf cross-section showing silica cells in the epidermis. (E) Fluorescence micrograph of prickles at the leaf tip in S. bicolor visualized by alkali-induced fluorescence (Soukup et al., 2014). (F) SEM of S. bicolor root cross-section showing silica aggregates anchored in the inner tangential cell walls of endodermis. (G) Alkali-induced fluorescence micrograph of $S$. bicolor primary root showing extensive distribution of silica aggregates in the endodermis. Root cortex was mechanically removed to expose the inner tangential cell walls. Cx, cortex; En, endodermis; Ep, epidermis; LR, lateral root; ma, macro-hair; p, papilla; Pc, pericycle; PR, primary root; pr, prickle cell; sa, silica aggregate; sc, silica cell; st, stoma. SEMs were collected at the back scattered electron mode, rendering silicon atoms brighter than carbon atoms.

In long cells, the outer wall thickens about 1 week after glume emergence. Silica deposition seems to initiate 2 weeks after the glume emergence, in parallel to cell death and collapse of the long cells and parenchymatic cells (Hodson et al., 1985). Thus, long cell silicification seems to depend on water evaporation.

\section{The Outer Epidermal Cells and Macro-Hairs in Lemma}

The outer epidermis of the lemma of Phalaris canariensis lacks stomata, suggesting low transpiration rates (Tambussi et al., 2007). Silicification, however, occurs in macro-hairs and typical rectangular epidermal cells (Hodson et al., 1984), a trait common to many grasses. Before panicle emergence, both the macro-hairs and outer epidermal cells have a large vacuole. The presence of $\mathrm{Si}$ was not detected at this stage. Figure 1C shows a scanning electron micrograph of a $T$. aestivum glume, exhibiting papillae, and macro-hairs, but no stomata.

Macro-hairs are unicellular trichomes, often with lengths greater than $1 \mathrm{~mm}$ on Phalaris canariensis lemma (Perry et al., 1984a). Macro-hairs also start to silicify after panicle emergence. Silica deposition initiates at the hair tip (Perry et al., 1984b). During the week following emergence, wall thickening proceeds to the base, and the outer layer of the wall is silicified. The nanometric morphology of the deposited silica is governed by the newly laid-down polysaccharides. Sheetlike structures form during the deposition of arabinosylated xylan and cellulose, globular particles deposit simultaneously with mixed linkage $\beta$ - $(1 \rightarrow 3,1 \rightarrow 4)$-D-glucan, and fibrous silica forms after the cell wall thickening stops. Apparently, the polysaccharides provide chemical environments necessary to stabilize the deposited silica (Perry et al., 1987). By 2 weeks after emergence, silicification of the wall material continues in concentric rings (Hodson et al., 1984; Perry et al., 1984a). The cytoplasmic content of macro-hairs breaks down leaving behind an empty lumen (Hodson et al., 1984).

Deposition of silica at the outer epidermal cells is also templated by their cell wall. At emergence, the inner tangential cell walls thicken to occupy most of the cell volume, leaving only little space for active cytoplasm. In the week following emergence, cytoplasm degrades and silicification initiates in the cell wall region close to the pre-existing cytoplasm. Within 2 weeks, the whole cell wall is impregnated with silica (Hodson et al., 1984). We conclude that in macro-hairs and outer epidermal cells of the 

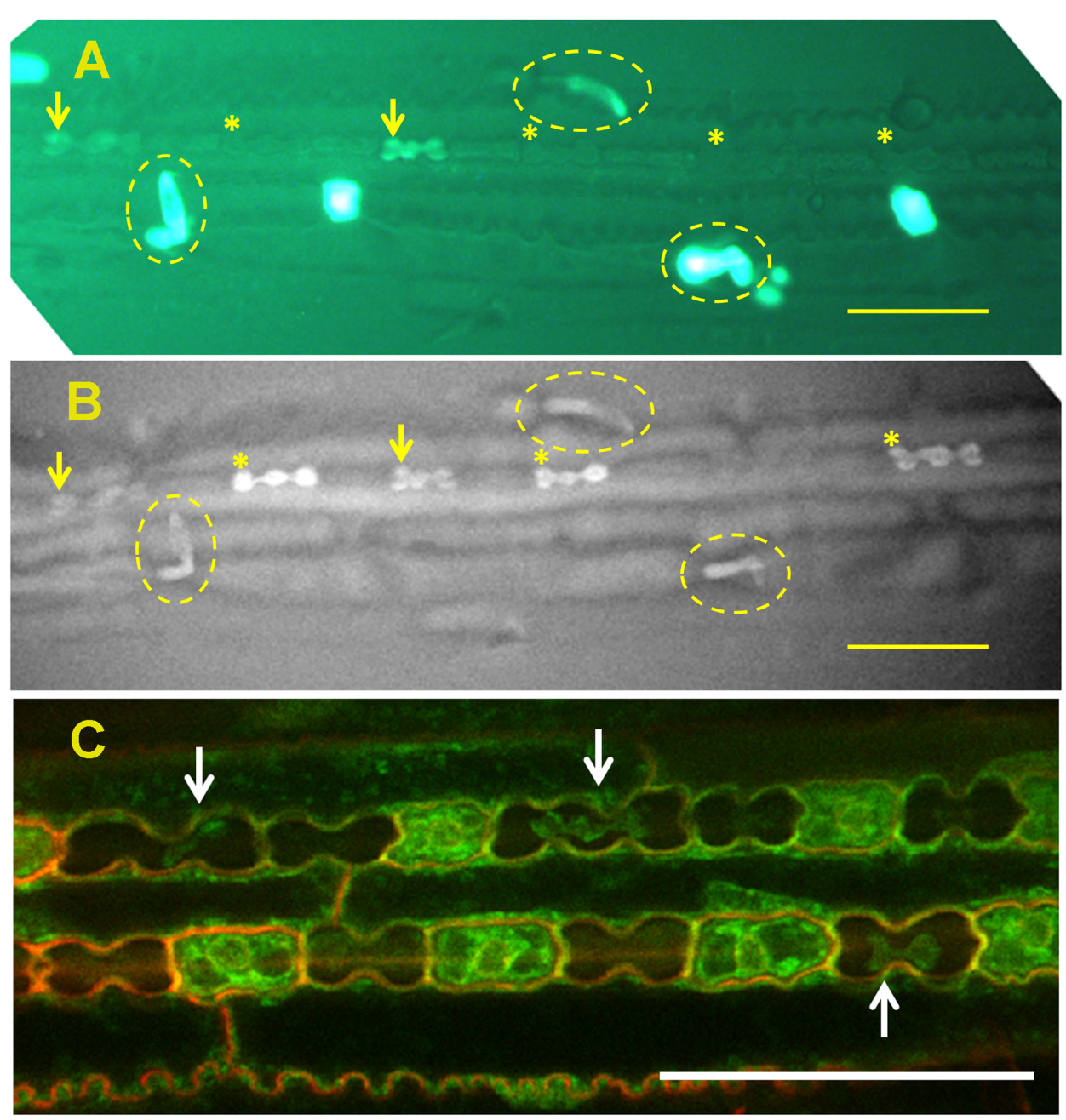

FIGURE 2 | Silica deposition in the epidermis of sorghum leaf. (A) Viability assay of epidermal peel showing viable cells' cytoplasm green. Viable silica cells are indicated with arrows whereas dead silica cells are indicated with asterisks. Micro-hairs are shown with broken ovals. (B) Back-scattered electron micrograph of the same field of view, showing high signal intensity emanating from viable silica cells (arrow) and micro-hairs (broken oval). Dead silica cells are already silicified (asterisks), although one dead non-silicified silica cell can also be seen [compare (A,B)]. (C) Silica cells displaying shrunken but viable cytoplasm (arrows) indicating extra-membranous silica deposition. All scale bars represent $50 \mu \mathrm{m}$. Images adapted from Kumar et al., (2017) with permission from the John Wiley and Sons publications. Copyrights of the image rest with the original authors and publisher.

lemma, silicification templated by the cell wall coincides with the onset of spikelet transpiration.

\section{Leaf Silicification}

Among all plant organs, leaves usually exhibit highest transpiration volumes. The evaporation of water promotes xylem sap condensation and contributes to the formation of solute sediments, including silica. However, even though most of the water evaporates from mesophyll cells and passes through stomata to the atmosphere, silicification of the guard cells occurs at slow pace, advances with age, and never reaches all of the cells (Figures 1D,E), (Motomura et al., 2004). Among other epidermal cell types, long cells accumulate silica in their walls as soon as the leaf starts to transpire (Sakai and Sanford, 1984). Silicification in the mesophyll and bulliform cell walls is rather characteristic to mature, sometimes senescent leaves (Sangster, 1970; Dinsdale et al., 1979). Silicification is probably spontaneous in the cell wall of these cells, resulting from Si auto-polymerization. In case of lumen silicification in bulliform cells, granules of silica are observed (Motomura et al., 2004).

\section{Silicification of Leaf Micro-Hairs}

Micro-hairs are bicellular trichomes having a basal and a cap cell. Basal cells of micro-hairs in sugarcane are the first cell type to silicify, even before leaf exposure to the outside environment (Sakai and Sanford, 1984). In sorghum, silicification of the basal cell initiates in viable cells (Figure 2), probably at the cell wall. The cells probably die later on, and their lumen passively fills up with silica (Motomura et al., 2000). In bamboo (Sasa veitchii), cap cells accumulate significant amounts of silica only after leaf opening. The number of silicified micro-hairs increases 
with age (Motomura et al., 2004), suggesting a dependency on transpiration. Silicification in micro-hairs seems thus to share similar mechanism to prickle hairs and papillae in the inflorescence bracts.

\section{Silica Deposition in Silica Cells}

In grasses, silica cells are found as stretches of silica-cork cell pairs in the epidermis of leaves (Sangster, 1970), stem internodes (Kaufman et al., 1969) and abaxial epidermis of glumes (Hodson et al., 1985). Silica cells are among the first type of cells to be silicified in a tissue, sometimes even before the tissue is exposed to the atmosphere (Kaufman et al., 1969; Sangster, 1970; Motomura et al., 2006; Kumar et al., 2017). The silica deposition occurs over hours (Blackman, 1969; Kaufman et al., 1969), suggesting that the process is metabolically controlled. In rice, the walls of silica cells lignify before silica deposition (Zhang et al., 2013). Prior to silica deposition, silica cells are metabolically very active with large nucleus and high numbers of ribosomes and mitochondria. Silica cells are well connected to their neighboring cork cells, but not to the neighboring long cells (Lawton, 1980). Silica cells are viable at the time of silica deposition. The mineralization process initiates in the extra-membranous space and proceeds centripetally (Figure 2). The forming mineral is limited by the cell wall on one side and by the membrane on the other side. The shrunk cytoplasm maintains its viability and the deposited silica does not interfere with cell-to-cell diffusion (Kumar et al., 2017). Silica deposition occurs also in leaf segments with very limited transpiration flow (Sangster and Parry, 1971; Kumar et al., 2017). The deposition is reduced in leaves treated with a metabolic inhibitor 2,4-dinitrophenol (Sangster and Parry, 1971) and does not occur in dead silica cells present in live leaves (Markovich et al., 2015; Kumar et al., 2017). These findings further indicate on a metabolic process controlling the silicification.

Organic matter with N/C ratio indicative of amino acids is continuously distributed in wheat silica cells (Alexandre et al., 2015), suggesting possible role of proteins in the templating process, similar to diatoms (Kröger et al., 1999). Depending upon the phytolith extraction process, some of nitrogen detected may result from the use of nitric acid in the extraction process or represent acid hydrolyzed proteins occluded within the silica structure (Watling et al., 2011), even without their direct participation in silicification.

\section{Silicification in Roots}

Roots are the first organs exposed to silicic acid, allowing its uptake and controlling the extent of Si supply to the entire plant. In most cases, the deposition of silica in roots cannot rely on evaporation of water for concentrating silicic acid. A passive mode of silicification in roots thus assumes that $\mathrm{Si}$ condensation occurs as water is absorbed by the symplasm, leaving behind concentrated silicic acid solution in the apoplasm (Exley, 2015). Such separation may occur at the Casparian bands, where the passive diffusion of $\mathrm{Si}$ and water is blocked (Sakurai et al., 2015). Indeed, in the aerial parts of adventitious roots of Phalaris canariensis, silica deposition occurs in the epidermis and outer cortical layer, but not in the endodermis (Hodson, 1986). This observation suggests the involvement of transpiration in silica deposition in these aerial roots. However, transpiration-dependent model does not conform to silicification at the endodermal inner tangential walls, which are located centripetally to the Casparian bands (Sangster, 1978). Depending on the grass species, silica impregnates the endodermal inner tangential and radial cell walls (Parry and Soni, 1972; Hodson and Sangster, 1989; Lux et al., 2003a), or forms discrete aggregates anchored in the inner tangential wall (Sangster and Parry, 1976a; Parry and Kelso, 1977; Sangster, 1977) (Figures 1F,G).

The active uptake of Si that bypasses the Casparian bands occurs at the apical part of roots. Afterward, $\mathrm{Si}$ is transferred with the transpiration stream basipetally through the central cylinder (Lux et al., 2003b; Soukup et al., 2017). While most of the $\mathrm{Si}$ is transported to the shoot, some $\mathrm{Si}$ binds to the root endodermis with high affinity (Markovich et al., 2015). Endodermal silicification is usually associated with the thickening of inner tangential walls and the deposition of polyphenols suberin and lignin in the mature parts of the roots (Parry and Kelso, 1975; Sangster and Parry, 1976a). Since Si is taken up actively in the root apex, the mature endodermis is supplied with Si by its centrifugal flow from the central cylinder. This model was evidenced in sorghum, where the aerial parts of adventitious roots silicified even before reaching the growth medium (Sangster and Parry, 1976b). Accordingly, silica deposition was detected in the basal parts of roots grown with Si supply provided to their apices only (Lux et al., 2003b), even if the cortical tissues between those regions were removed (Soukup et al., 2017).

In sorghum, silica aggregation initiates in non-lignified sites of the inner tangential cell walls, possibly templated by arabinoxylan-ferulic acid complexes. The aggregation sites are established even in the absence of $\mathrm{Si}$, indicating that the formation of silica aggregates is at least partially controlled by the structure and composition of the endodermal cell walls (Soukup et al., 2017). The aggregates seem to swell the silicifying wall and protrude from the endodermal inner tangential wall toward the cell lumen (Figure 1F).

In older roots, the deposition of silica can extend also to other root regions, e.g., to the outer tangential walls of endodermis or intercellular spaces of cortex. Such deposition is probably a result of Si condensation due to water uptake by the symplasm, water evaporation, or it can be induced by increasing ionic strength of the apoplasm or $\mathrm{pH}$ changes. With the increasing age of the roots, stele, sclerenchyma and conductive tissues may also silicify (Parry and Kelso, 1975; Montgomery and Parry, 1979; Hodson and Sangster, 1989).

\section{CONCLUSION}

Transpiration plays a major role in moving Si throughout the plant. Water evaporation and water uptake by the symplasm can efficiently condense Si and lead to silica precipitation. However, uncontrolled and spontaneous silica deposition may be harmful for the functioning of the plant. The evolution of mechanisms for a safe disposal of Si was thus essential. Based on the matrix that templates the silicification and the participation of transpiration in this process, we identified three types of silica deposition in 
grasses that describe silicification in most of the cell types. (1) Passive cell wall silicification: This type is distinctive to mature and/or intensely transpiring organs, where the condensation of $\mathrm{Si}$ is driven by dehydration. A continuous supply of $\mathrm{Si}$ infiltrates the non-silicified cell walls and its deposition occurs without being metabolically controlled by the cells. (2) Controlled cell wall silicification: Silica is deposited directly on the cell wall matrix, even before the organ is exposed to the atmosphere/transpiration. Silicification is possibly templated by the cell wall polymers inducing the silicic acid polymerization. In some cases, the cell protoplast dies, allowing spontaneous silica deposition driven by transpiration in the cell lumen, without further organic template. (3) Silica cells are a special case, where the mineral is deposited on the external side of a functional plasma membrane, possibly in a volume that contains materials that enhance silica deposition, independent of transpiration.

Thus we saw, a plant as a whole does not follow one silicification mechanism but the observed mechanism is specific

\section{REFERENCES}

Alexandre, A., Basile-Doelsch, I., Delhaye, T., Borshneck, D., Mazur, J. C., Reyerson, P., et al. (2015). New highlights of phytolith structure and occluded carbon location: 3-D X-ray microscopy and NanoSIMS results. Biogeosciences 12, 863-873. doi: 10.5194/bg-12-863-2015

Bauer, P., Elbaum, R., and Weiss, I. M. (2011). Calcium and silicon mineralization in land plants: transport, structure and function. Plant Sci. 180, 746-756. doi: 10.1016/j.plantsci.2011.01.019

Bennett, D. M. (1982). An ultrastructural study on the development of silicified tissues in the leaf tip of barley (Hordeum sativum Jess). Ann. Bot. 50, 229-237. doi: $10.1098 /$ rspb.1984.0074

Bennett, D. M., and Parry, D. W. (1981). Electron-probe microanalysis studies of silicon in the epicarp hairs of the caryopses of Hordeum sativum Jess., Avena sativa L., Secale cereale L. and Triticum aestivum L. Ann. Bot. 48, 645-654. doi: 10.1093/oxfordjournals.aob.a086173

Blackman, E. (1969). Observations on the development of the silica cells of the leaf sheath of wheat (Triticum aestivum). Can. J. Bot. 47, 827-844. doi: 10.1139/ b69-120

Currie, H. A., and Perry, C. C. (2007). Silica in plants: biological, biochemical and chemical studies. Ann. Bot. 100, 1383-1389. doi: 10.1093/aob/mcm247

Currie, H. A., and Perry, C. C. (2009). Chemical evidence for intrinsic "Si" within Equisetum cell walls. Phytochemistry 70, 2089-2095. doi: 10.1016/j.phytochem. 2009.07.039

Detmann, K. C., Araújo, W. L., Martins, S. C. V., Fernie, A. R., and DaMatta, F. M. (2013). Metabolic alterations triggered by silicon nutrition. Is there a signaling role for silicon? Plant Signal. Behav. 8:e22523. doi: 10.4161/psb. 22523

Dinsdale, D., Gordon, A. H., and George, S. (1979). Silica in the mesophyll cell walls of Italian rye grass (Lolium multiflorum Lam. cv. RvP). Ann. Bot. 44, 73-77. doi: 10.1093/oxfordjournals.aob.a085708

Epstein, E. (1994). The anomaly of silicon in plant biology. Proc. Natl. Acad. Sci. U.S.A. 91, 11-17. doi: 10.1073/pnas.91.1.11

Euliss, K. W., Dorsey, B. L., Benke, K. C., Banks, M. K., and Schwab, A. P. (2005). The use of plant tissue silica content for estimating transpiration. Ecol. Eng. 25, 343-348. doi: 10.1016/j.ecoleng.2005.06.003

Exley, C. (2015). A possible mechanism of biological silicification in plants. Front. Plant Sci. 6:853. doi: 10.3389/fpls.2015.00853

Guerriero, G., Hausman, J.-F., and Legay, S. (2016). Silicon and the plant extracellular matrix. Front. Plant Sci. 7:463. doi: 10.3389/fpls.2016. 00463

Haynes, R. J. (2014). A contemporary overview of silicon availability in agricultural soils. J. Plant Nutr. Soil Sci. 177, 831-844. doi: 10.1002/jpln.201400202 to the cell-type chosen for study. Sometimes, a cell type follows two stage silicification: the early stage being cell wall silicification followed by granular silica deposition in the dead lumen. Thus, silicification in grasses is not an entirely active or passive process, and its mechanism is cell-type specific.

\section{AUTHOR CONTRIBUTIONS}

SK prepared the initial draft. All authors commented, added and revised the manuscript and approved for publication.

\section{ACKNOWLEDGMENTS}

This work was supported by the Israel Science Foundation grant 534/14. SK gratefully acknowledges the Planning and Budgeting Committee (PBC), The Council of Higher Education, Israel for a postdoctoral fellowship.

Hayward, D. M., and Parry, D. W. (1973). Electron-probe microanalysis studies of silica distribution in barley (Hordeum sativum L.). Ann. Bot. 37, 579-591. doi: 10.1093/oxfordjournals.aob.a084723

Hayward, D. M., and Parry, D. W. (1975). Scanning electron microscopy of silica deposition in the leaves of barley (Hordeum sativum L.). Ann. Bot. 39, 1003-1009. doi: 10.1093/oxfordjournals.aob.a085018

He, C., Wang, L., Liu, J., Liu, X., Li, X., Ma, J., et al. (2013). Evidence for “silicon" within the cell walls of suspension-cultured rice cells. New Phytol. 200, 700-709. doi: $10.1111 / \mathrm{nph} .12401$

Hodson, M. J. (1986). Silicon deposition in the roots, culm and leaf of Phalaris canariensis L. Ann. Bot. 58, 167-177. doi: 10.1093/oxfordjournals.aob.a087194

Hodson, M. J. (2016). The development of phytoliths in plants and its influence on their chemistry and isotopic composition. Implications for palaeoecology and archaeology. J. Archaeol. Sci. 68, 62-69. doi: 10.1016/j.jas.2015.09.002

Hodson, M. J., and Parry, D. W. (1982). The ultrastructure and analytical microscopy of silicon deposition in the aleurone layer of the caryopsis of Setaria italica (L). Beauv. Ann. Bot. 50, 221-228. doi: 10.1093/oxfordjournals. aob.a086359

Hodson, M. J., and Sangster, A. G. (1988). Silica deposition in the inflorescence bracts of wheat (Triticum aestivum). I. Scanning electron microscopy and light microscopy. Can. J. Bot. 66, 829-838. doi: 10.1139/b88-121

Hodson, M. J., and Sangster, A. G. (1989). Subcellular localization of mineral deposits in the roots of wheat (Triticum aestivum L.). Protoplasma 151, 19-32. doi: 10.1007/BF01403298

Hodson, M. J., Sangster, A. G., and Parry, D. W. (1984). An ultrastructural study on the development of silicified tissues in the lemma of Phalaris canariensis L. Proc. R. Soc. Lond. B Biol. Sci. 222, 413-425. doi: 10.1098/rspb.1984.0074

Hodson, M. J., Sangster, A. G., and Parry, D. W. (1985). An ultrastructural study on the developmental phases and silicification of the glumes of Phalaris canariensis L. Ann. Bot. 55, 649-665. doi: 10.1098/rspb.1984.0074

Hodson, M. J., White, P. J., Mead, A., and Broadley, M. R. (2005). Phylogenetic variation in the silicon composition of plants. Ann. Bot. 96, 1027-1046. doi: 10.1093/aob/mci255

Jones, L. H. P., Milne, A. A., and Wadham, S. M. (1963). Studies of silica in the oat plant. II. Distribution of the silica in the plant. Plant Soil 18, 358-371. doi: 10.1007/BF01347235

Kaufman, P. B., Bigelow, W. C., Petering, L. B., and Drogosz, F. B. (1969). Silica in developing epidermal cells of avena internodes: electron microprobe analysis. Science 166, 1015-1017. doi: 10.1126/science.166.3908.1015

Kido, N., Yokoyama, R., Yamamoto, T., Furukawa, J., Iwai, H., Satoh, S., et al. (2015). The matrix polysaccharide $(1 ; 3,1 ; 4)-\beta$-d-glucan is involved in silicondependent strengthening of rice cell wall. Plant Cell Physiol. 56, 268-276. doi: $10.1093 / \mathrm{pcp} / \mathrm{pcu} 162$ 
Kröger, N., Deutzmann, R., and Sumper, M. (1999). Polycationic peptides from diatom biosilica that direct silica nanosphere formation. Science 286, 1129-1132. doi: 10.1126/science.286.5442.1129

Kumar, S., Milstein, Y., Brami, Y., Elbaum, M., and Elbaum, R. (2017). Mechanism of silica deposition in sorghum silica cells. New Phytol. 213, 791-798. doi: $10.1111 / \mathrm{nph} .14173$

Law, C., and Exley, C. (2011). New insight into silica deposition in horsetail (Equisetum arvense). BMC Plant Biol. 11:112. doi: 10.1186/1471-2229-11-112

Lawton, J. R. (1980). Observations on the structure of epidermal cells, particularly the cork and silica cells, from the flowering stem internode of Lolium temulentum L. (Gramineae). Bot. J. Linn. Soc. 80, 161-177. doi: 10.1111/j.10958339.1980.tb01663.x

Liang, Y., Nikolic, M., Belanger, R., Gong, H., and Song, A. (2015). Silicon in Agriculture: From Theory to Practice. New York, NY: Springer Publishing. doi: 10.1016/S0928-3420(01)80010-0

Lux, A., Luxová, M., Abe, J., Morita, S., and Inanaga, S. (2003a). Silicification of bamboo (Phyllostachys heterocycla Mitf.) root and leaf. Plant Soil 255, 85-91. doi: 10.1023/A:1026157424794

Lux, A., Luxová, M., Abe, J., Tanimoto, E., Hattori, T., and Inanaga, S. (2003b). The dynamics of silicon deposition in the sorghum root endodermis. New Phytol. 158, 437-441. doi: 10.1046/j.1469-8137.2003.00764.x

Ma, J. F., and Yamaji, N. (2006). Silicon uptake and accumulation in higher plants. Trends Plant Sci. 11, 392-397. doi: 10.1016/j.tplants.2006.06.007

Ma, J. F., and Yamaji, N. (2015). A cooperative system of silicon transport in plants. Trends Plant Sci. 20, 435-442. doi: 10.1016/j.tplants.2015.04.007

Ma, J. F., Yamaji, N., and Mitani-Ueno, N. (2011). Transport of silicon from roots to panicles in plants. Proc. Jpn. Acad. Ser. B Phys. Biol. Sci. 87, 377-385. doi: $10.2183 /$ pjab.87.377

Markovich, O., Kumar, S., Cohen, D., Addadi, S., Fridman, E., and Elbaum, R. (2015). Silicification in leaves of sorghum mutant with low silicon accumulation. Silicon, 1-7. doi: 10.1007/s12633-015-9348-x

Montgomery, D. J., and Parry, D. W. (1979). The ultrastructure and analytical microscopy of silicon deposition in the intercellular spaces of the roots of Molinia caerulea (L.) Moench. Ann. Bot. 44, 79-84. doi: 10.1093/oxfordjournals. aob.a085709

Motomura, H., Fujii, T., and Suzuki, M. (2000). Distribution of silicified cells in the leaf blades of Pleioblastus chino (Franchet et Savatier) Makino (Bambusoideae). Ann. Bot. 85, 751-757. doi: 10.1006/anbo.2000.1124

Motomura, H., Fujii, T., and Suzuki, M. (2004). Silica deposition in relation to ageing of leaf tissues in Sasa veitchii (Carriere) Rehder (Poaceae: Bambusoideae). Ann. Bot. 93, 235-248. doi: 10.1093/aob/mch034

Motomura, H., Fujii, T., and Suzuki, M. (2006). Silica deposition in abaxial epidermis before the opening of leaf blades of Pleioblastus chino (Poaceae, Bambusoideae). Ann. Bot. 97, 513-519. doi: 10.1093/aob/mcl014

Nissan, H., Blum, S., Shimoni, E., and Elbaum, R. (2015). Characterization of silicon accumulation in maize cell suspension cultures. Silicon doi: 10.1007/ s12633-015-9347-y

Parry, D. W., Hodson, M. J., and Sangster, A. G. (1984). Some recent advances in studies of silicon in higher plants. Philos. Trans. R. Soc. B Biol. Sci. 304, 537-549. doi: $10.1098 /$ rstb.1984.0045

Parry, D. W., and Kelso, M. (1975). Distribution of silicon deposits in the roots of Molinia caerulea (L.) Moench. and Sorghum bicolor (L.) Moench. Ann. Bot. 39, 995-1001. doi: 10.1093/oxfordjournals.aob.a085043

Parry, D. W., and Kelso, M. (1977). The ultrastructure and analytical microscopy of silicon deposits in the roots of Saccharum officinarum (L.). Ann. Bot. 41, 855-862. doi: 10.1093/oxfordjournals.aob.a085361

Parry, D. W., and Soni, S. L. (1972). Electron-probe microanalysis of silicon in the roots of Oryza sativa L. Ann. Bot. 36, 781-783. doi: 10.1093/oxfordjournals.aob. a084633

Perry, C. C., Mann, S., and Williams, R. J. P. (1984a). Structural and analytical studies of the silicified macrohairs from the lemma of the grass Phalaris canariensis L. Proc. R. Soc. Lond. B Biol. Sci 222, 427-438. doi: 10.1098/rspb. 1984.0075

Perry, C. C., Mann, S., Williams, R. J. P., Watt, F., Grime, G. W., and Takacs, J. (1984b). A scanning proton microprobe study of macrohairs from the lemma of the grass Phalaris canariensis L. Proc. R. Soc. Lond. B Biol. Sci. 222, 439-445. doi: $10.1086 / 303379$
Perry, C. C., Williams, R. J. P., and Fry, S. C. (1987). Cell wall biosynthesis during silicification of grass hairs. J. Plant Physiol. 126, 437-448. doi: 10.1016/S01761617(87)80028-7

Raven, J. A. (1983). The transport and function of silicon in plants. Biol. Rev. 58, 179-207. doi: 10.1111/j.1469-185X.1983.tb00385.x

Rosen, A. M., and Weiner, S. (1994). Identifying ancient irrigation: a new method using phytoliths from emmer wheat. J. Archaeol. Sci. 21, 125-132. doi: 10.1006/ jasc. 1994.1013

Sakai, W. S., and Sanford, W. G. (1984). A developmental study of silicification in the abaxial epidermal cells of sugarcane leaf blades using scanning electron microscopy and energy dispersive X-ray analysis. Am. J. Bot. 71, 1315-1322. doi: $10.2307 / 2443698$

Sakurai, G., Satake, A., Yamaji, N., Mitani-Ueno, N., Yokozawa, M., Feugier, F. G., et al. (2015). In silico simulation modeling reveals the importance of the casparian strip for efficient silicon uptake in rice roots. Plant Cell Physiol. 56, 631-639. doi: 10.1093/pcp/pcv017

Salmén, L. (2015). Wood morphology and properties from molecular perspectives. Ann. For. Sci. 72, 679-684. doi: 10.1007/s13595-014-0403-3

Sangster, A. G. (1970). Intracellular silica deposition in immature leaves in three species of the Gramineae. Ann. Bot. 34, 245-257. doi: 10.1093/oxfordjournals. aob.a084359

Sangster, A. G. (1977). Electron-probe microassay studies of silicon deposits in the roots of two species of Andropogon. Can. J. Bot. 55, 880-887. doi: 10.1139/b77-107

Sangster, A. G. (1978). Silicon in the roots of higher plants. Am. J. Bot. 65, 929-935. doi: $10.2307 / 2442679$

Sangster, A. G., Hodson, M. J., Parry, D. W., and Rees, J. A. (1983). A developmental study of silicification in the trichomes and associated epidermal structures of the inflorescence bracts of the grass, Phalaris canariensis L. Ann. Bot. 52, 171-187. doi: 10.1093/oxfordjournals.aob.a086563

Sangster, A. G., Hodson, M. J., and Tubb, H. J. (2001). "Silica deposition in higher plants," in Silicon in Agriculture, eds L. E. Datnoff, G. H. Snyder, and G. H. Korndorfer (Amsterdam: Elsevier Science B. V), 85-113. doi: 10.1007/978-161779-927-3

Sangster, A. G., and Parry, D. W. (1971). Silica deposition in the grass leaf in relation to transpiration and the effect of dinitrophenol. Ann. Bot. 35, 667-677. doi: 10.1093/oxfordjournals.aob.a084511

Sangster, A. G., and Parry, D. W. (1976a). Endodermal silicon deposits and their linear distribution in developing roots of Sorghum bicolor (L.) Moench. Ann. Bot. 40, 361-371. doi: 10.1093/oxfordjournals.aob.a085139

Sangster, A. G., and Parry, D. W. (1976b). The ultrastructure and electronprobe microassay of silicon deposits in the endodermis of the seminal roots of Sorghum bicolor (L.) Moench. Ann. Bot. 40, 447-459. doi: 10.1093/ oxfordjournals.aob.a085153

Schoelynck, J., Bal, K., Backx, H., Okruszko, T., Meire, P., and Struyf, E. (2010). Silica uptake in aquatic and wetland macrophytes: a strategic choice between silica, lignin and cellulose? New Phytol. 186, 385-391. doi: 10.1111/j.1469-8137. 2009.03176.x

Soukup, M., Martinka, M., Bosnić, D., Čaplovičová, M., Elbaum, R., and Lux, A. (2017). Formation of silica aggregates in sorghum root endodermis is pre-determined by cell wall architecture and development. Ann. Bot. (in press).

Soukup, M., Martinka, M., Cigáň, M., Ravaszová, F., and Lux, A. (2014). New method for visualization of silica phytoliths in Sorghum bicolor roots by fluorescence microscopy revealed silicate concentration-dependent phytolith formation. Planta 240, 1365-1372. doi: 10.1007/s00425-0142179-y

Suzuki, S., Ma, J. F., Yamamoto, N., Hattori, T., Sakamoto, M., and Umezawa, T. (2012). Silicon deficiency promotes lignin accumulation in rice. Plant Biotechnol. 29, 391-394. doi: 10.5511/plantbiotechnology.12.0416a

Tambussi, E. A., Bort, J., Guiamet, J. J., Nogues, S., and Araus, J. L. (2007). The photosynthetic role of ears in C3 cereals: metabolism, water use efficiency and contribution to grain yield. Crit. Rev. Plant Sci. 26, 1-16. doi: 10.1080/ 07352680601147901

Watling, K. M., Parr, J. F., Rintoul, L., Brown, C. L., and Sullivan, L. A. (2011). Raman, infrared and XPS study of bamboo phytoliths after chemical digestion. Spectrochim. Acta A Mol. Biomol. Spectrosc. 80, 106-111. doi: 10.1016/j.saa. 2011.03 .002 
Yamaji, N., Sakurai, G., Mitani-Ueno, N., and Ma, J. F. (2015). Orchestration of three transporters and distinct vascular structures in node for intervascular transfer of silicon in rice. Proc. Natl. Acad. Sci. U.S.A. 112, 11401-11406. doi: 10.1073/pnas.1508987112

Yamamoto, T., Nakamura, A., Iwai, H., Ishii, T., Ma, J. F., Yokoyama, R., et al. (2012). Effect of silicon deficiency on secondary cell wall synthesis in rice leaf. J. Plant Res. 125, 771-779. doi: 10.1007/s10265-0120489-3

Yoshida, S., Ohnishi, Y., and Kitagishi, K. (1962). Chemical forms, mobility and deposition of silicon in rice plant. Soil Sci. Plant Nutr. 8, 15-21. doi: 10.1080/ 00380768.1962.10430992

Zhang, C., Wang, L., Zhang, W., and Zhang, F. (2013). Do lignification and silicification of the cell wall precede silicon deposition in the silica cell of the rice
(Oryza sativa L.) leaf epidermis? Plant Soil 372, 137-149. doi: 10.1007/s11104013-1723-z

Conflict of Interest Statement: The authors declare that the research was conducted in the absence of any commercial or financial relationships that could be construed as a potential conflict of interest.

Copyright (c) 2017 Kumar, Soukup and Elbaum. This is an open-access article distributed under the terms of the Creative Commons Attribution License (CC BY). The use, distribution or reproduction in other forums is permitted, provided the original author(s) or licensor are credited and that the original publication in this journal is cited, in accordance with accepted academic practice. No use, distribution or reproduction is permitted which does not comply with these terms. 